\title{
Persepsi Suharto dan Perubahan Kebijakan Luar Negeri Indonesia terhadap Cina pada Awal Orde Baru
}

\author{
Hafid Adim Pradana \\ Universitas Muhammadiyah Malang
}

\begin{abstract}
Leadership change from Sukarno to Suharto had given impact to Indonesia foreign policies. One of many changes of Indonesia foreign policies in Suharto regime is the severance of diplomatic relations with China. This paper aim to explain the Indonesia's foreign policy change in that time, especially the severance of diplomatic relations with China in 1967. Despite it becomes a historical relic, a case study of Indonesia's foreign policy under Suharto remains important since there have been no specific research focusing on the severance of diplomatic relations between Indonesia and China. Using Perception Theory from Ole R. Holsti as the tool of analysis, this paper concludes that the deteriorating relations between Indonesia and China in 1967 was influenced by Suharto's perception considered that China is a threat to Indonesia following the attempted coup in 1965.
\end{abstract}

Keywords: Suharto's perception, Indonesia's foreign policy, China

\begin{abstract}
Abstrak
Pergantian kepemimpinan dari Sukarno ke Suharto berdampak pada perubahan politik luar negeri Indonesia. Salah satu perubahan politik luar negeri pada masa Suharto ialah pemutusan hubungan diplomatik dengan Cina. Tulisan ini berupaya untuk menjelaskan perubahan kebijakan luar negeri Indoenesia pada saat itu, terutama pemutusan hubungan diplomatic dengan Cina pada 1967. Meskipun sudah menjadi peninggalan sejarah, studi kasus tentang kebijakan luar negeri Suharto masih penting dikaji mengingat belum terdapat riset yang secara khusus berfokus pada kebijakan Indonesia dalam memutuskan hubungan diplomatik dengan Cina. Menggunakan Teori Persepsi yang dirumuskan oleh Ole R. Holsti sebagai alat analisa, penelitian ini menyimpulkan bahwa memburuknya hubungan diplomatik antara Indonesia dan Cina pada 1967 disebabkan oleh persepsi Suharto yang menganggap CINA sebagai ancaman Indonesia menyusul peristiwa upaya kudeta tahun 1965.
\end{abstract}

Kata-kata kunci: persepsi Suharto, kebijakan luar negeri Indonesia, Cina 
“Terhadap siapa pun yang akan mengembalikan PKI di Indonesia,
alat-alat negara akan bertindak dengan tegas"

[Suharto]

\section{Pendahuluan}

Pergantian rezim pemerintahan senantiasa diikuti oleh perubahan kebijakan luar negeri. Di Indonesia, hal ini tampak pada masa pergantian kepemimpinan Sukarno ke Suharto. Pergantian rezim tersebut secara langsung turut mempengaruhi perubahan kebijakan luar negeri Indonesia. Salah satu perubahan kebijakan luar negeri Indonesia yang paling menonjol ialah pemutusan diplomatik dengan Cina (dahulu bernama Republik Rakyat Tiongkok) pada 1967 (Suryadinata, 1998:130131). Sebagaimana diketahui, bahwa pada masa Sukarno, khususnya pada periode 1959-1965, Indonesia dan Cina memiliki kedekatan hubungan diplomatik, yang ditunjukkan dengan adanya poros Jakarta-Beijing. Akan tetapi, tidak lama setelah Suharto berkuasa, yaitu pada Oktober 1967, Indonesia memutuskan hubungan diplomatiknyadengan Cina.

Berdasarkan fenomena tersebut, permasalahan yang kemudian muncul ialah, mengapa terjadi pemutusan hubungan diplomatik terhadap Cina pada awal kepemimpinan Suharto? Tulisan ini selanjutnya akan menjelaskan mengenai penyebab terjadinya perubahan kebijakan luar negeri Indonesia terhadap Cina pada awal masa Orde Baru. Pendekatan teoritis yang dipakai dalam menjelaskan pertanyaan tersebut ialah teori persepsi yang dirumuskan oleh Ole R. Holsti. Teori tersebut secara umum menjelaskan bahwa kebijakan luar negeri yang dijalankan oleh suatu negara merupakan hasil dari persepsi pemimpin negara yang dipengaruhi oleh sistem keyakinan berupa fakta, yaitu citra tentang apa yang telah, sedang dan akan terjadi, dan nilai, yaitu citra tentang apa yang seharusnya terjadi. Sistem keyakinan tersebut selanjutnya akan membentuk persepsi pemimpin negara yang kemudian berpengaruh dalam pengambilan keputusan (Mas'oed, 1991:20-21). Berdasarkan teori persepsi tersebut, tesis dasar tulisan ini adalah kebijakan Suharto memutuskan hubungan diplomatik dengan Cina dipengaruhi oleh persepsi Suharto dalam melihat Cina sebagai ancaman keamanan bagi Indonesia.

Tulisan ini memakai metode studi kasus, yaitu suatu metode penelitian yang berfokus pada investigasi mendalam terhadap suatu kasus. Bennet (2004:20-21) sebagaimana dituliskan oleh Rosyidin (2015:128), menyampaikan bahwa "kasus" yang dimaksud dalam hal ini ialah peristiwa sejarah yang sudah terjadi yang dipilih peneliti untuk 
dianalisa. Meskipun peristiwa-peristiwa masa lampau merupakan 'building block' yang menyusun bangunan ilmu Hubungan Internasional (HI), banyak penstudi yang berpendapat bahwa peristiwa sejarah bukan termasuk dalam lingkup penelitian HI (Rosyidin, 2015:129). Sebagai bidang studi interdisipliner, HI secara umum ialah hasil perpaduan antara beberapa bidang studi seperti sejarah, politik, ekonomi, dan hukum (Hermawan dalam Pareira, 1999:4-5) . Sejarah memainkan peran penting dalam penelitian HI dikarenakan peristiwa-peristiwa yang telah terjadi kadangkala masih menyimpan teka-teki yang belum terpecahkan sehingga menyediakan lahan subur bagi peneliti untuk melakukan riset mendalam baik untuk tujuan verifikasi teori maupun falsifikasi teori (Rosyidin, 2015:130). Maka dari itu, meskipun kasus yang dikaji dalam tulisan ini merupakan peristiwa yang sudah sangat lama, akan tetapi masih dianggap penting guna membuktikan relevansi dari teori persepsi Ole R. Holsti dalam menjelaskan faktor putusnya hubungan diplomatik Indonesia-Cina pada masa awal pemerintahan Suharto.

Tulisan ini terbagi menjadi lima bagian. Bagian pertama merupakan tinjauan berbagai literatur yang membahas tentang politik luar negeri Indonesia pada masa Suharto, terutama dalam kasus putusnya hubungan diplomatik dengan Cina. Pemaparan tersebut penting untuk menunjukkan bahwa penelitian ini, meskipun mengambil kasus lama, menawarkan pendekatan berbeda yang belum pernah dipakai dalam penelitian-penelitian sebelumnya. Bagian kedua akan mengelaborasi penjelasan teori persepsi yang dirumuskan oleh Ole R. Holsti. Bagian ketiga akan mendeskripsikan hubungan politik Indonesia dengan Cina pada masa Orde Lama, khususnya dalam periode demokrasi terpimpin (1957-1965). Bagian keempat memaparkan perubahan hubungan politik Indonesia dengan Cina pada masa Orde Baru dan penjelasan mengenai penyebab berubahnya politik luar negeri Indonesia terhadap Cina pada masa Orde Baru, khususnya terkait dengan pemutusan hubungan diplomatik terhadap Cina. Bagian terakhir adalah kesimpulan.

\section{Kebijakan Luar Negeri Suharto terhadap Cina: Tinjauan Literatur}

Secara umum belum ada literatur yang mengkaji secara spesifik kasus pemutusan hubungan diplomatik Indonesia-Cina pada awal masa kepemimpinan Suharto. Literatur mengenai politik luar negeri Indonesia terhadap Cina pada masa Suharto kebanyakan berfokus pada dinamika hubungan kedua negara selama masa Orde Baru. Tulisan Suryadinata (1998) yang berjudul 'Hubungan Indonesia-Cina: Ideologi, Etnis Cina, dan 
Presiden' secara umum memaparkan tentang politik luar negeri Indonesia terhadap Cina selama masa Orde Baru. Dalam tulisannya tersebut, Suryadinata menjelaskan hubungan Indonesia-Cina dari awal kepemimpinan Suharto sampai dengan tahun 1992-1993. Pada bagian awal tulisannya, Suryadinata secara singkat memaparkan hubungan Indonesia-Cina pada masa Sukarno, sebelum kemudian menjelaskan perubahan arah politik luar negeri Indonesia terhadap Cina pada awal masa Orde Baru, yang ditandai oleh putusnya hubungan diplomatik antara kedua negara.

Kebijakan Indonesia memutusan hubungan diplomatik dengan Cina, menurut Suryadinata disebabkan oleh pandangan militer dan kelompok antikomunis yang berkuasa yang melihat Cina sebagai pihak yang dianggap turut terlibat dalam peristiwa G30S. Bagian selanjutnya dalam tulisan Suryadinata, lebih banyak membahas tentang proses normalisasi hubungan Indonesia-Cina beserta perbedaan pandangan antar elit penguasa di Indonesia dalam melihat prospek normalisasi hubungan kedua negara pada akhir 1970-an dan sepanjang 1980-an. Di akhir tulisannya, Suryadinata memaparkan berbagai isu yang dapat mempengaruhi hubungan Indonesia-Cina di masa mendatang, seperti masalah di Laut Cina Selatan, persoalan wilayah perairan Natuna, hingga hubungan Indonesia-Taiwan.

Secara umum, tulisan dari Suryadinata memiliki kesamaan topik dengan tulisan ini, yaitu sama-sama meneliti tentang politik luar negeri Indonesia terhadap Cina pada masa Suharto. Perbedaannya terletak pada fokus pembahasannya. Suryadinata lebih berfokus pada pemaparan secara menyeluruh tentang hubungan Indonesia-Cina, sedangkan tulisan ini lebih berfokus pada kebijakan Indonesia dalam memutuskan hubungan diplomatic dengan Cina. Selain itu, secara teoritis, dalam menjelaskan faktor putusnya hubungan Indonesia dengan Cina, Suryadinata lebih menyoroti pandangan militer, sebagai elit penguasa baru di Indonesia pasca tumbangnya Sukarno, yang pada saat itu memandang Cina sebagai negara pendukung Partai Komunis Indonesia (PKI). Berbeda dengan itu, tulisan ini menganalisis faktor putusnya hubungan Indonesia-Cina dengan memfokuskan pada persepsi Suharto sebagai pemeran utama dalam proses pengambilan kebijakan luar negeri.

Literatur-literatur lain, seperti Smith (2003) dan Nabbs-Keller (2001) juga menjelaskan tentang dinamika hubungan Indonesia-Cina pada masa Suharto, sebagaimana ditulis oleh Suryadinata. Akan tetapi penjelasan tersebut hanya merupakan salah satu sub-bahasan dalam tulisan tersebut. 
Baik karya Smith maupun Nabbs-Keller tidak berfokus pada hubungan Indonesia-Cina pada masa Suharto. Dalam tulisannya, Smith berfokus pada prospek kerjasama Indonesia-Cina pasca Orde Baru. Sedangkan karya Nabbs-Keller lebih berfokus pada implikasi semakin membaiknya hubungan Indonesia-Cina terhadap politik luar negeri Australia.

Karya yang lain misalnya tulisan Alami (dalam Wuryandari, 2008) secara umum membahas tentang politik luar negeri Indonesia pada masa Orde Baru. Dalam tulisannya tersebut, Alami tidak mencantumkan subbab khusus yang membahas tentang hubungan Indonesia-Cina pada masa Suharto. Pembahasan mengenai hubungan Indonesia-Cina dalam tulisan tersebut tampak pada sub-bab pertama tulisannya yang memaparkan tentang arah dan prinsip politik luar negeri Indonesia pada masa Orde Baru. Pada bagian tersebut, perubahan politik luar negeri Indonesia pada masa Suharto tidak dapat dilepaskan dari pemikiran Suharto yang berorientasi pada upaya mencapai stabilitas politik keamanan dan pembangunan ekonomi (Alami dalam Wuryandari, 2008:115). Pemikiran Suharto tersebut tidak dapat dilepaskan dari kondisi instabilitas politik dan krisis ekonomi yang sedang terjadi pada saat itu. Kondisi itulah yang mendorong Suharto berpikir bahwa untuk mengangkat Indonesia dari krisis ekonomi diperlukan kondisi politik dan keamanan dalam negeri yang stabil serta lingkungan eksternal yang dami (Alami dalam Wuryandari, 2008:116). Oleh karena itu, guna mencapai stabilitas politik keamanan, Suharto mengambil kebijakan untuk menumpas PKI yang dianggap sebagai aktor utama instabilitas politik dan keamanan dalam negeri. Pada gilirannya hal tersebut berdampak pada memburuknya hubungan Indonesia dengan Cina. Konsekuensinya, politik luar negeri Indonesia mengalami perubahan orientasi dari Blok Timur ke Blok Barat. Hal ini tampak dari kebijakan memperbaiki hubungan dengan negaranegara Barat seperti Amerika Serikat dan Inggris, guna mendapatkan bantuan dan kerjasama ekonomi (Alami dalam Wuryandari, 2008:119120).

Dalam menjelaskan buruknya hubungan Indonesia-Cina yang berpuncak pada putusnya hubungan diplomatik antara kedua negara, Alami berfokus pada penekanan tentang dinamika politik dan ekonomi dalam negeri. Dari sini dapat dilihat bahwa pembahasan Alami memiliki beberapa perbedaan dengan tulisan ini. Pertama, secara keseluruhan tulisan Alami berfokus pada politik luar negeri Indonesia pada masa Orde Baru, sedangkan tulisan ini berfokus untuk menjelaskan alasan kebijakan Indonesia dalam memutuskan hubungan diplomatik dengan Cina pada 
awal masa Orde Baru. Kedua, tulisan Alami menggunakan variabel dinamika politik dan ekonomi dalam negeri untuk menjelaskan politik luar negeri Indonesia pada masa Orde Baru, termasuk dalam menjelaskan faktor buruknya hubungan Indonesia-Cina, sementara tulisan ini menggunakan teori persepsi yang menekankan pada faktor di balik pemutusan hubungan diplomatik dengan Cina.

\section{Memahami Kebijakan Luar Negeri menggunakan Teori Persepsi}

Secara umum terdapat dua tipe teori yang dapat dipakai dalam menjelaskan fenomena politik internasional. Teori tipe pertama ialah teori reduksionis, yaitu teori yang memusatkan perhatian pada tingkat individu atau nasional. Sedangkan teori tipe kedua ialah teori sistemik, yaitu teori yang berfokus pada penjelasan tentang sistem internasional (Waltz, 1979:18). Teori politik luar negeri merupakan tipe teori yang berada pada level nasional (Waltz, 1979:72), serta berfokus pada penjelasan mengenai proses pengambilan kebijakan dan alasan yang melatarbelakangi tindakan yang dijalankan oleh suatu negara (Holsti, 1992:26).

Salah satu pendekatan dalam teori politik luar negeri ialah pendekatan mikro, yaitu pendekatan yang berfokus pada tingkat analisis individu. Para teoritisi yang menerapkan tingkat analisis individu berasumsi bahwa pengetahuan politik ialah pengetahuan tentang manusia, yakni pengetahuan tentang bagaimana manusia berpikir tentang dirinya sendiri, bagaimana mereka memandang dunia dan tempat hidup mereka didalamnya, dan apa yang menurut mereka penting dalam hidup mereka. Oleh karena itu, untuk memahami dunia politik, maka perlu untuk terlebih dulu mengetahui mengapa manusia melakukan tindakan politik dan apa hubungan antara tindakan tersebut dengan kebutuhan, kehendak, citra, nilai, dan keyakinan manusia. Dalam konteks politik luar negeri, asumsi dasar para teoritisi mikro ialah bahwa tindakan luar negeri suatu negara tidaklah dijalankan oleh negara bangsa itu sendiri, tetapi oleh para pemimpinnya (Mas'oed, 1991:1-2).

Dari sekian banyak teori politik luar negeri dalam pendekatan mikro, tulisan ini mengambil teori persepsi yang dirumuskan oleh Ole Holsti sebagai alat analisa guna menjawab permasalahan dalam tulisan ini. Berbeda dengan teorisasi tentang naluri manusia dalam pengambilan kebijakan yang memandang perilaku manusia lebih banyak ditentukan oleh naluri, teorisasi mengenai persepsi dalam pengambilan kebijakan mengasumsikan bahwa naluri dan kepribadian adalah segi-segi 
individual yang bersifat statis, sedangkan persepsi atau 'citra' yang dimiliki individu bersifat dinamis karena persepsi seringkali berubah. Boulding (dalam Mas'oed, 1991:19) mengatakan, “Kita harus mengakui bahwa orang-orang yang menentukan kebijaksanaan dan tindakan negara-negara tidak melakukan tanggapan terhadap fakta-fakta situasi yang 'objektif' . . . tetapi terhadap 'citra' mereka tentang situasi itu, yang menentukan perilaku kita adalah persepsi kita tentang dunia, bukan kenyataan dunia itu."

Pernyataan Boulding diatas menunjukkan bahwa persepsi seorang pemimpin memainkan peranan dalam menentukan perilaku suatu negara. Franck dan Weisband (dalam Mas'oed, 1991:19) juga menekankan pentingnya citra dengan berpendapat bahwa, "Cara dua negara saling melihat satu sama lain sering menentukan cara mereka berinteraksi. Suatu pola kerjasama yang sistematik tidak mungkin berkembang diantara negara-negara yang masing-masing menganggap lawan sebagai jahat, agresif dan tidak bermoral."

Dengan demikian, individu melakukan tindakan berdasarkan apa yang ia ketahui. Tanggapan individu pada suatu situasi tergantung pada bagaimana ia mendefinisikan situasi itu.

Mengenai hubungan antara citra, persepsi, dan perilaku internasional, Russet dan Starr (dalam Mas'oed, 1991:20) memberikan penjelasan bahwa dalam proses pembuatan keputusan politik luar negeri, pada awalnya timbul suatu situasi atau masalah. Sebelum situasi atau masalah itu muncul untuk ditanggapi oleh para pembuat keputusan, ada tiga hal yang terjadi. Pertama, ada semacam stimulus dari lingkungan. Kedua, tentu ada upaya untuk mempersepsi stimulus itu. Ini adalah proses yang diterapkan oleh individu untuk menyeleksi, menata, dan menilai informasi yang masuk tentang dunia sekitarnya. Ketiga, harus ada upaya menafsirkan stimulus yang telah dipersepsi itu. Persepsi dan penafsiran itu sangat tergantung pada citra yang ada dalam benak si pembuat keputusan.

Tahapan-tahapan yang telah dijelaskan oleh Russet dan Starr digambarkan oleh Ole Holsti dalam sebuah diagram yang menggambarkan persepsi dan hubungannya dengan citra dan sistem keyakinan (lihat Gambar 1). Menurut Holsti (1985:304), sistem keyakinan terdiri dari serangkaian citra yang membentuk keseluruhan kerangka acuan atau sudut pandang seseorang. Citra-citra itu meliputi realitas masa lalu, masa kini, dan realitas yang diharapkan di masa depan, dan preferensi nilai tentang apa yang seharusnya terjadi. 
Teori persepsi dalam pandangan Holsti membedakan tiga komponen persepsi, yaitu nilai, keyakinan dan pengetahuan atau fakta (Jones, 1992:276). Nilai adalah preferensi terhadap pernyataan realitas tertentu dibanding realitas lainya. Nilai memberikan harga relatif kepada objek dan kondisi. Keyakinan adalah benar, terbukti atau telah diketahui. Keyakinan sering didasarkan pada penerimaan informasi yang sebelumnya dari lingkungan, meskipun hal itu tidak sama dengan data sendiri. Ini adalah suatu pernyataan analitis yang menghubungkan satuan-satuan data kedalam suatu pola 'yang teruji'. Sedangkan pengetahuan atau fakta yang ada dan yang diketahui, bersumber dari data atau informasi yang diterima dari lingkungan. Pengetahuan merupakan unsur kunci dalam pembentukan dan perubahan sistem perseptual.

Para pembuat keputusan umumnya dipengaruhi oleh berbagai proses psikologi yang mempengaruhi persepsi itu, misalnya untuk merasionalisasikan tindakan, untuk mempertahankan pendapat sendiri, untuk mengurangi kecemasan, dan lain sebagainya. Russet dan Starr (dalam Mas'oed, 1991:21) menjelaskan bagaimana citra seseorang mempengaruhi persepsinya tentang dunia sekitarnya melalui proses sebagai berikut:

\section{Gambar 1 Hubungan antara sistem keyakinan dengan pembuatan keputusan politik luar negeri}

INPUT

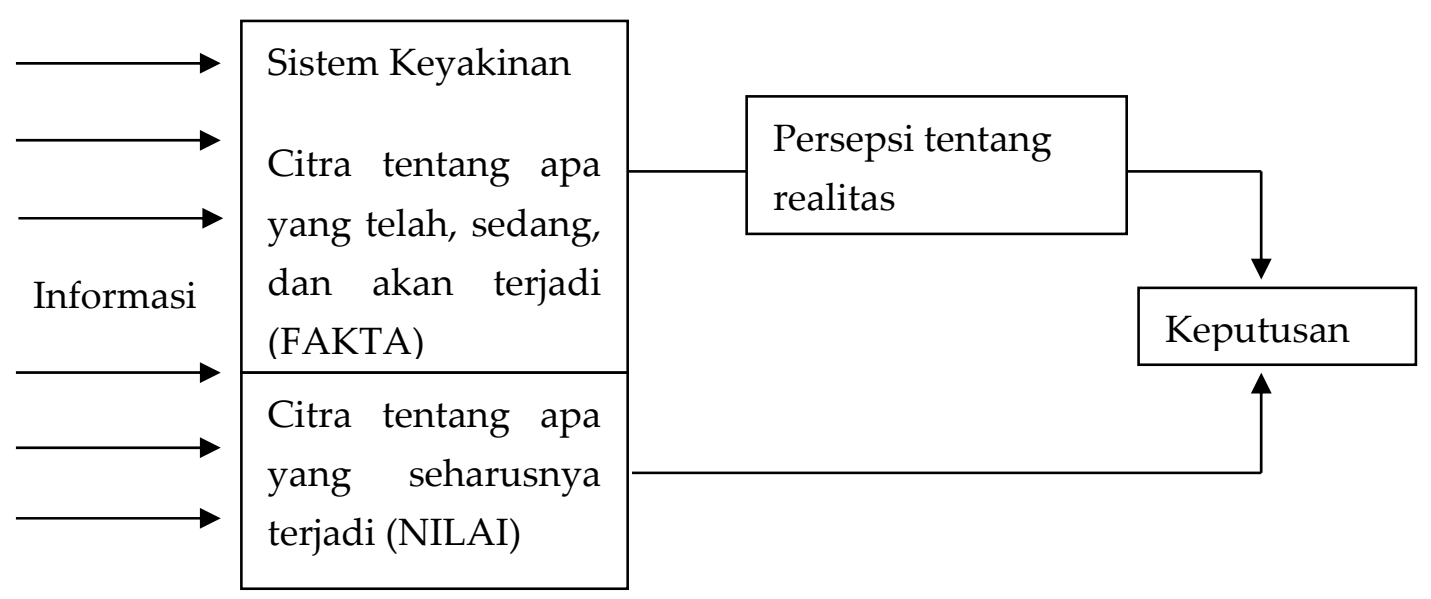

Sumber: Holsti (dalam Russet \& Starr, sebagaimana dikutip oleh Mas'oed, 1991:21). 
Berdasarkan Gambar 1 diatas, secara singkat dapat dijelaskan bahwa pada awalnya individu menerima berbagai informasi. Informasi yang diterima tersebut kemudian tersaring dalam sistem keyakinan yang dianut. Sistem keyakinan sendiri terdiri dari fakta, yaitu citra tentang apa yang telah, sedang, dan akan terjadi, serta nilai, yaitu citra tentang apa yang seharusnya terjadi. Melalui fakta, individu kemudian memiliki persepsi tentang realitas, yang kemudian mendorongnya untuk mengambil keputusan. Adapun nilai berfungsi sebagai panduan langsung dalam mengambil keputusan. Dengan demikian, dalam melihat kebijakan luar negeri perlu untuk melihat bagaimana persepsi seorang individu pengambil keputusan yang dipengaruhi oleh sistem keyakinannya.

\section{Hubungan Indonesia-Cina pada Masa Orde Lama}

Bagian ini akan memberikan gambaran umum tentang politik luar negeri Indonesia terhadap Cina pada masa kepemimpinan Sukarno, khususnya pada periode demokrasi terpimpin dari tahun 1959 sampai dengan 1965. Selain itu, bagian ini juga akan menjelaskan dinamika politik dalam negeri Indonesia pada masa tersebut yang turut mempengaruhi kebijakan luar negeri pada masa Sukarno.

Demokrasi terpimpin merupakan suatu istilah yang oleh banyak pakar disematkan pada periode ahir kepemimpinan Sukarno. Awal periode demokrasi terpimpin ditandai oleh keluarnya Dekrit Presiden pada 5 Juli 1959 yang menyerukan pemberlakuan kembali UndangUndang Dasar 1945. Hal ini pada gilirannya membawa dampak luas bagi pemerintahan Indonesia, terutama berkaitan dengan fungsi presiden yang tidak lagi hanya sekedar simbolik tetapi telah kembali sebagai pemegang kekuasaan eksekutif yang berperan besar dalam mengambil keputusan (Wuryandari, 2008:92).

Pada awal periode demokrasi terpimpin, bidang politik luar negeri kurang mendapatkan perhatian Sukarno. Ini tidak bisa dilepaskan dari fokus Sukarno yang lebih memprioritaskan upaya konsolidasi politik dalam negeri. Upaya tersebut dilakukan Sukarno dengan melakukan politik keseimbangan antara aktor-aktor politik, terutama antara tentara dan PKI yang memiliki pengaruh besar pada saat itu (Wuryandari, 2008:92-93). Secara politis, hal ini memang perlu dilakukan karena tentara memiliki posisi yang cukup kuat dalam perpolitikan Indonesia, terutama setelah berhasil menumpas pemberontakan PRRI-Permesta tahun 1958. Selain itu, kokohnya posisi tentara turut didorong oleh pemberlakuan Undang-Undang Darurat yang memberikan keleluasaan kewenangan 
tentara dalam menggunakan kekuasaannya. Ini bisa dilihat dari keterlibatan tentara dalam kegiatan-kegiatan ekonomi dan juga meningkatkan jumlah persenjataannya (Wuryandari, 2008:93). Di sisi lain, PKI juga memiliki kedudukan yang semakin mantap. Hal ini disebabkan karena secara organisatoris PKI mampu memaksimalkan kekuatannya. Kemenangan PKI dalam pemilihan propinsi tahun 1957 di beberapa daerah merupakan bukti kuat kemampuan partai tersebut dalam memobilisasi dan memperluas basis massa. Selain itu, secara politis Sukarno cenderung memberikan ruang kepada PKI dengan mengurangi kekuasaan Angkatan Darat.

Pada akhirnya, apa yang diupayakan Sukarno berhasil menciptakan situasi politik dalam negeri yang kondusif sekalipun masih terdapat manuver-manuver politik antara pelaku utama politik dalam negeri Indonesia, yaitu tentara, PKI, dan Sukarno sendiri (Wuryandari, 2008:93-94). Semakin kondusifnya kondisi politik dalam negeri membuat Sukarno mulai memperhatikan urusan-urusan luar negeri. Meskipun di dalam negeri tentara dan PKI semakin berperan penting dalam percaturan politik Indonesia, namun Presiden Sukarno merupakan aktor yang paling berpengaruh dalam penentuan kebijakan luar negeri Indonesia. Sebagaimana halnya pada periode sebelumnya, kebijakan luar negeri Indonesia di era demokrasi terpimpin pada 1960-an sama-sama berfokus pada perjuangan melawan imperialisme, kolonialisme, dan neokolonialisme. Perbedaannya, kebijakan luar negeri Indonesia menjadi semakin militan dalam perjuangannya tersebut, yang oleh Sukarno disebut sebagai nekolim (Wuryandari, 2008:94). Wujud militansi kebijakan luar negeri Indonesia tampak dari upaya Sukarno dalam merebut Irian Barat pada 1963. Selain itu, meskipun masalah Irian Barat berhasil terselesaikan, Sukarno tetap melanjutkan kebijakan anti-kolonialismenya dengan melakukan kampanye untuk mencegah terbentuknya Federasi Malaysia pada 1963.

Berdasarkan hal tersebut, secara umum dapat dilihat bahwa politik luar negeri Indonesia pada masa demokrasi terpimpin bersifat lebih militan anti-kolonial dan anti-Barat (Suryadinata, 1998:38) Pada masa itu, Indonesia secara tidak resmi bersekutu dengan negara-negara komunis dan sosialis. Persekutuan antara Indonesia dengan negara-negara komunis dan sosialis dapat dilihat dari klasifikasi dunia yang dilakukan oleh Sukarno, dimana pada masa tersebut Sukarno mengklasifikasikan dunia menjadi dua dua bagian yang meliputi Oldefos (Old Established Forces), dan Nefos (New Established Forces). Oldefos terdiri dari negara- 
negara Barat, sedangkan Nefos terdiri dari negara-negara komunis dan negara-negara baru Asia-Afrika. Menyikapi politik luar negeri Indonesia yang mulai mengacu pada klasifikasi tersebut, Amerika Serikat (AS) berupaya membujuk Sukarno agar lebih kompromis. Akan tetapi keinginan AS tersebut ditolak oleh Sukarno, yang menyebabkan ketegangan berkepanjangan antara Jakarta dengan Washington (Suryadinata, 1998:39).

Ketegangan Indonesia-AS menunjukkan bahwa Indonesia memilih untuk lebih berorientasi pada hubungan dengan Blok Timur. Membaiknya hubungan Indonesia dengan blok Timur ditunjukkan dengan adanya ide pendirian CONEFO (Conference of New Emerging Forces) oleh Sukarno sebagai organisasi tandingan bagi Perserikatan Bangsa-Bangsa (PBB). Ide pembentukan CONEFO tersebut mendapat dukungan kuat dari Cina yang memberikan bantuan dana untuk membangun markas besar organisasi tandingan PBB tersebut di Jakarta. Negara-negara komunis lain, seperti Korea Utara dan Vietnam Utara kemudian ikut bergabung dalam CONEFO, dan selanjutnya terciptalah poros Jakarta-Hanoi-Pyongyang-Beijing, dengan aksi dan orientasi antiBarat (Suryadinata, 1998:38).

Hubungan Indonesia-Cina selama periode demokrasi terpimpin tidak selalu lancar. Pada awalnya, Indonesia memperkenalkan kebijakan yang melarang etnis Tionghoa untuk terlibat dalam kegiatan perdagangan di pedesaan. Hal tersebut membuat sebagian masyarakat etnis Tionghoa kembali ke Cina. Situasi ini sempat menimbulkan merenggangnya hubungan Indonesia-Cina. Di tengah kondisi tersebut, terdapat suatu kelompok yang dipimpin oleh militer untuk memperburuk hubungan Indonesia-Cina dengan mendorong Indonesia agar lebih dekat dengan Uni Soviet. Khawatir jika Indonesia lebih dekat ke Uni Soviet, pemerintah Cina memutuskan untuk mengabaikan masalah etnis Tionghoa di Indonesia, dan memilih untuk memperkuat hubungan baik dengan Indonesia. Hal ini kemudian ditindak lanjuti oleh Sukarno dengan melakukan pembendungan terhadap kampanye anti-Cina (Suryadinata, 1998:41). Tindakan yang dilakukan oleh Soekarno ini dilandasi oleh kesamaan tujuan antara Indonesia dan RRT yang sama-sama menentang imperialisme (Bunnel, 1966: 40).

Meskipun sempat diwarnai isu diskriminasi etnis Tionghoa, hubungan Indonesia-Cina pada masa tersebut secara umum berjalan dengan baik. Kedekatan hubungan dua negara tersebut dipengaruhi oleh adanya kesamaan pandangan yang cenderung anti-Barat. Meskipun 
demikian, tidak semua elemen dalam negeri Indonesia mendukung kedekatan hubungan Jakarta-Beijing. Dalam hal ini, pihak militer merupakan pihak yang paling khawatir akan kedekatan hubungan antara kedua negara. Kekhawatiran pihak militer tidak terlepas dari dinamika politik dalam negeri yang sedang berlangsung pada saat itu, yakni terus berkembangnya pengaruh PKI setelah pemilu tambahan tahun 1957 dan kecenderungan Sukarno yang orientasi politiknya mulai bergeser ke kiri (Suryadinata, 1998:129).

Persaingan antara militer dan PKI pada masa Sukarno semakin memanas. Menyadari akan kedekatannya dengan Sukarno, PKI berinisiatif untuk mendirikan Angkatan Kelima yang terdiri dari petani dan buruh. Presiden Sukarno memberikan dukungan terhadap ide tersebut dengan mengirim Omar Dhani, kepala Staf Angkatan Udara (AU) untuk berunding dengan Cina dengan harapan akan mendapatkan bantuan berupa senjata-senjata ringan bagi Angkatan Kelima. Kenyataan kemudian menunjukkan bahwa Sukarno menginginkan perimbangan kekuatan militer melalui penggabungan diri dengan PKI dan AU. Perimbangan kekuasaan ini tiba-tiba berakhir pada tanggal 30 September 1965 ketika terjadi upaya kudeta. Kudeta tersebut berakibat pada dihapuskannya PKI, jatuhnya Sukarno, dan menguatnya kedudukan militer di Indonesia. Suharto kemudian muncul sebagai orang baru yang berhasil melakukan manuver terhadap kelompok-kelompok lain dan mengambil kepemimpinan dari Sukarno pada 1966.

Sampai di sini dapat dilihat bahwa peran Sukarno sebagai seorang pemimpin negara sangat dominan dalam menentukan arah politik luar negeri Indonesia. Pada masa demokrasi terpimpin, Sukarno mengarahkan politik luar negeri Indonesia untuk lebih condong berpihak pada blok sosialis-komunis yang ditandai dengan menguatnya hubungan antara Inonesia dan Cina. Berakhirnya kepemimpinan Sukarno tidak lantas menghilangkan dominasi pemimpin negara dalam mengarahkan politik luar negeri Indonesia. Suharto, yang naik menggantikan Sukarno juga memiliki peran dominan dalam menentukan arah politik luar negeri Indonesia. Bagian selanjutnya akan membahas tentang pengaruh persepsi Suharto yang menentukan perubahan hubungan luar negeri IndonesiaCina. 


\section{Persepsi Suharto dan Kebijakan Pemutusan Hubungan Diplomatik Indonesia-Cina}

Pergantian rezim kepemimpinan suatu negara senantiasa berpengaruh pada perubahan kebijakan luar negeri di negara tersebut. Begitu pula yang terjadi dengan Indonesia pasca jatuhnya Sukarno,yang digantikan oleh Suharto. Sebagaimana telah disinggung sebelumnya, hubungan Indonesia-Cina berjalan cukup baik pada masa Sukarno. Akan tetapi hubungan kemudian tersebut mengalami perubahan drastis pasca naiknya Suharto ke kursi kekuasaan. Perubahan tersebut tidak dapat dilepaskan dari pemikiran awal yang disampaikan oleh Suharto dalam pidatonya di depan Majelis Permusyarawatan Rakyat Sementara (MPRS) pada 1966 yang memuat dua hal utama yaitu stabilitas politik keamanan dan pembangunan ekonomi. Pembangunan ekonomi tidak dapat dilaksanakan secara baik, tanpa adanya stabilitas politik keamanan dalam negeri maupun di tingkat regional. Guna mewujudkan pemikirannya tersebut, di dalam negeri Suharto mengambil keputusan membubarkan PKI (Wuryandari, 2008:157-158). Hal ini berdampak pada memburuknya hubungan Indonesia dengan negara-negara Blok Komunis, sehingga dalam konteks luar negeri, Suharto mengambil langkah perubahan kebijakan luar negeri dengan membangun hubungan baik dengan pihakpihak Barat, serta menerapkan 'good neighbourhood policy' melalui Association South East Asia Nations (ASEAN). Keberpihakan Indonesia terhadap Barat tidak bisa dilepaskan dari mendesaknya kebutuhan ekonomi pada saat itu sehingga Suharto berupaya mencari bantuan luar negeri ke negara-negara Barat.

Dari kondisi-kondisi seperti itu, dapat dilihat bahwa segera setelah Suharto berkuasa Indonesia mulai meninggalkan politik luar negeri yang cenderung kekiri-kirian. Hal ini tampak dari adanya dugaan akan keterlibatan Cina dalam upaya kudeta yang (dituduhkan) dilakukan oleh PKI yang berujung pada putusnya hubungan diplomatik dengan Cina pada Oktober 1967 (Smith, 2003:2). Meskipun demikian, peran Cina dalam kudeta tersebut dinilai masih tetap kabur.

Ada dua pandangan mengapa peran Cina dalam upaya kudeta tersebut masih kabur. Pertama, Cina menyetujui kudeta dan memasok persenjataan "diluar sepengetahuan dan kontrol otoritas militer Indonesia". Para pejabat Cina di Beijing mengetahui kudeta enam jam setelah peristiwa tersebut berlangsung dan memberikan daftar jenderal Indonesia yang seharusnya dibunuh. Kelompok medis Cina yang didatangkan dari Beijing memberikan informasi kepada D.N. Aidit - 
pimpinan PKI - mengenai gawatnya kondisi kesehatan Sukarno sehingga mendorong PKI melakukan kudeta yang gagal. Laporan CIA kemudian mengungkapkan bahwa tidak ada bukti kuat keberadaan Cina di balik kudeta tersebut. Tetapi laporan itu menyebutkan bahwa "karena ketika Aidit berkunjung ke Cina dan awal persiapan PKI untuk kudeta hampir bersamaan dengan kembalinya Ia dari Cina, suatu kasus yang dibuat berdasarkan bukti tidak langsung menunjukkan bahwa Cina telah memberikan inspirasi terjadinya kudeta di Indonesia" (Suryadinata, 1998:130).

Kedua, terdapat pandangan yang menyatakan bahwa Beijing tidak menyetujui kudeta karena dua alasan. Pertama, situasi sebelum kudeta sangat menguntungkan Beijing, dan sukar untuk dipahami mengapa Beijing akan merencanakan kudeta yang akan memperburuk situasi. Adanya sejumlah kecil senjata buatan Cina setelah kudeta juga memberikan kesan bahwa Cina tidak terlibat. Kedua, adalah tidak mungkin bahwa partai komunis yang besar seperti PKI akan mendengar perintah dari Beijing (Suryadinata, 1998:130). Dalam tulisan ini, kontroversi mengenai keterlibatan Cina dalam kudeta gagal 1965 bukan suatu hal yang penting karena tulisan ini memfokuskan pada alasan Indonesia pada awal kepemimpinan Suharto melakukan pemutusan hubungan diplomatik dengan Cina.

Ketiadaaan bukti empiris yang menunjukkan keterlibatan Cina dalam kudeta tahun 1965 secara langsung menunjukkan bahwa pemutusan hubungan diplomatik dengan Cina merupakan suatu keanehan. Hal ini tentunya menjadi suatu pertanyaan besar mengapa negara yang tidak terlibat kudeta 1965 dimusuhi bahkan diputuskan hubungan diplomatiknya dengan Indonesia. Guna menjawab pertanyaan tersebut, tulisan ini melihat bahwa persepsi Suharto menjadi determinan yang dapat menjelaskan kasus putusnya hubungan diplomatik Indonesia dengan Cina. Secara teoritis, persepsi pemimpin negara dapat mempengaruhi kebijakan luar negeri negara yang dipimpinnya.

Dalam kasus tersebut, Suharto selaku pemimpin negara dan pengambil kebijakan luar negeri memiliki peran yang sangat besar. Persepsi Suharto dibentuk oleh sistem keyakinan yang dianutnya. Sistem keyakinan yang dianut Suharto tidak bisa dilepaskan dari latar belakang Suharto yang dikenal sangat menjunjung tinggi adat budaya Jawa (Wuryandari, 2008:118-119). Dengan latar belakang seperti itu maka wajar jika kemudian Suharto mempercayai bahwa seorang penguasa mesti 
mengikuti adat Jawa. Hal ini tentunya tidak dapat dilepaskan dari latar belakang personal Suharto yang lahir dari keluarga Jawa.

Soeharto lahir pada 8 Juni 1921 di desa Kemusuk, Godean, Yogyakarta. Ia merupakan anak ketiga dari Kertosudiro, seorang pengatur irigasi di desa Kemusuk. Tidak seperti saudara-saudaranya, yang berada langsung dalam asuhan orang tua Suharto, masa kecil Suharto ia lewati dibawah asuhan langsung kakeknya, mbah Kromo. Hal ini terlihat langsung dalam pengakuan Soeharto, sebagaimana dikutip oleh Vatikiotis (1993: 8), "Saya sering diundang oleh mbah Kromo ke sawah... Saya masih ingat bagaimana saya memberi perintah kerbau untuk bergerak maju, berbelok ke kiri atau kanan, kemudian jatuh di padi, bermain di air dan lumpur. Jika saya merasa lelah, atau panas, saya beristirahat di tepi lapangan... Saya dulu suka mencari belut, dan saya suka memakannya dengan sangat banyak, seperti yang saya lakukan sampai sekarang."

Melalui Mbah Kromo, Suharto mempelajari langsung kehidupan masyarakat Jawa. Selain dari Mbah Kromo, nilai-nilai Jawa yang melekat kuat dalam diri Suharto juga tidak bisa deilepaskan dari faktor budaya yang terdapat di desa Kemusuk, wilayah tempat lahir Suharto. Desa Kemusuk sendiri merupakan daerah yang kental dengan adat Jawa. Hal ini tidak dapat dilepaskan dari adanya fakta bahwa Pajang-DemakMataram merupakan pusat-pusat peradaban Jawa pasca runtuhnya Majapahit, dan Kemusuk, yang termasuk wilayah Yogyakarta-Wonogiri merupakan zona penyangga peradaban itu dimana didalamnya tersebar guru-guru spiritual Jawa yang dengan tekun mentransformasikan ajaranajaran itu kepada masyarakat. Salah satu guru spiritual yang sempat disebut Pak Harto -dalam buku Suharto: Pikiran, Ucapan dan Tindakan Saya yang diterbitkan PT Citra Kharisma Bunda Tahun 1989- adalah Kyai Daryatmo. Melalui Kyai Daryatmo, Suharto mempelajari nilai-nilai yang terkandung dalam budaya Jawa (Rohman, 2003).

Dibawah didikan mbah Kromo dan Kyai Daryatmo sebagai guru spiritualnya, Soeharto mempelajari langsung nilai-nilai budaya Jawa. Nilai-nilai Jawa yang dianut oleh Soeharto semakin kuat ketika ia menikah dengan Siti Hartinah, yang merupakan anak perempuan dari seorang pejabat Mangkunegaran (Suryadinata, 1998: 46-47).Berdasarkan kepatuhannya terhadap adat Jawa, Suharto memandang bahwa Jawa adalah pusat dunia. Pandangan ini berakar dari adanya sejarah panjang peradaban Jawa yang dalam perjalanannya pernah menguasai seluruh nusantara dan sebagian wilayah Asia Tenggara. Dalam sejarahnya pula, Jawa pernah terlibat konflik dengan Kekaisaran Cina. Konflik historis 
Jawa-Cina yang paling terkenal ialah invasi Kubilai Khan pada abad ke14. Meskipun pasukan dari Cina tersebut dapat diusir keluar, namun semenjak adanya invasi tersebut masyarakat Jawa memiliki pandangan bahwa Cina adalah suatu negara agresif yang senantiasa menjadi ancaman (Suryadinata, 1998:17).

Kuatnya pengaruh budaya Jawa pada diri Suharto membuatnya memiliki sistem keyakinan yang kental dengan budaya Jawa. Sistem keyakinan yang dimiliki oleh Suharto tersebut selanjutnya membentuk suatu penilaian mengenai "apa yang telah terjadi" dan "apa yang seharusnya terjadi." Penilaian tersebut selanjutnya membentuk persepsi Suharto dalam membuat suatu kebijakan. Berdasarkan teori yang digunakan dalam tulisan ini, secara ringkas pengaruh sistem keyakinan dan persepsi Suharto dalam kebijakan pemutusan hubungan diplomatik dengan Cina dapat dilihat melalui Gambar 2. Dari gambar tersebut, tampak bagaimana sistem keyakinan Suharto yang kental dengan adat budaya Jawa mempengaruhi persepsi Suharto dalam memandang Cina sebagai ancaman. Persepsi tersebut dibentuk oleh adanya penilaian Suharto terhadap "apa yang telah terjadi" dan "apa yang seharusnya terjadi."

Penilaian tentang "apa yang telah terjadi" dan "apa yang seharusnya terjadi" yang membentuk persepsi Suharto dalam hal ini berkaitan erat dengan peristiwa kudeta gagal 1965. Peristiwa tersebut merupakan informasi atau input yang diterima oleh Suharto. Berdasarkan input yang Ia terima, melalui sistem keyakinannya yang kental dengan pengaruh budaya Jawa, Suharto memandang bahwa peristiwa tersebut merupakan upaya kudeta oleh pihak komunis yang turut melibatkan Cina. Hal ini terlihat dari pernyataan Suharto dalam pidatonya di Hari Nasional pada 1967, dimana pada saat itu ia menyatakan bahwa keterlibatan Cina dalam kudeta tahun 1965 dan dukungan terhadap PKI yang terus berlanjut telah mengakibatkan hubungan yang tidak normal antara kedua negara (Suryadinata, 1998:131).

Dalam kaitannya dengan budaya Jawa yang Ia anut, Suharto mengkategorikan Cina sebagai pihak yang membantu 'durjana' atau 'penjahat', yang dalam hal ini ialah PKI. Bagi Suharto, penjahat lebih buruk daripada 'Klabang' atau 'Kalajengking' karena: “Klabang iku wisane ana ing sirah, kalajengking iku wisane mung ana pucuk buntut. Yen ula mung dumunung ana ula kang duwe wisa. Nanging yen durjana wisane dumunung ana ing sekujur badane" (Racun klabang/ binatang kaki seribu ada di kepala. Racun Kalajengking hanya di pucuk ekor. Racun ular hanya ada pada ular 
yang berbisa. Sedang penjahat racunnya terletak pada seluruh badannya) (Rohman, 2013). Dengan mengacu pada butir ajaran Jawa tersebut, maka pembenaran berperang terhadap penjahat disebabkan karena penjahat merupakan virus destruktif bagi terwujudnya ketenteraman bersama. Karena itulah, pada awal pemerintahannya Suharto berfokus pada upaya menghapus keberadaan PKI yang dianggap sebagai 'penjahat', sehingga pihak yang membantu PKI, yaitu Cina, tentunya juga dianggap sebagai 'penjahat' yang harus diperangi.

Persepsi Suharto yang memandang Cina sebagai ancaman semakin diperkuat oleh fakta bahwa Cina pada saat itu berada dalam kekuasaan Mao Zedong yang berambisi menyebarkan ide komunisme ke seluruh dunia. Dalam melakukan upayanya tersebut, Mao memberikan dukungan kepada setiap partai komunis di seluruh dunia untuk merebut kekuasaan di negara tempat mereka berada. Hal ini tidak bisa dilepaskan dari kebijakan Mao yang mengacu pada apa yang pernah dilakukan oleh Yoseph Stalin (Mannsbach \& Rafferty, 2012: 223). Maka dari itu, guna mengantisipasi tumbuhnya pengaruh komunisme dalam pemerintahannya, adalah wajar jika Suharto berani mengambil kebijakan untuk memutuskan hubungan diplomatik dengan Cina. Ketegasan ini tampak dari pernyataan Suharto dalam biografinya, dimana ia menyampaiakan bahwa: Terhadap siapa pun yang akan mengembalikan PKI di Indonesia, alat-alat negara akan bertindak dengan tegas (Rohman, 2003).

Gambar 2 Hubungan antara persepsi Suharto dan kebijakan pemutusan hubungan diplomatik dengan

INPUT

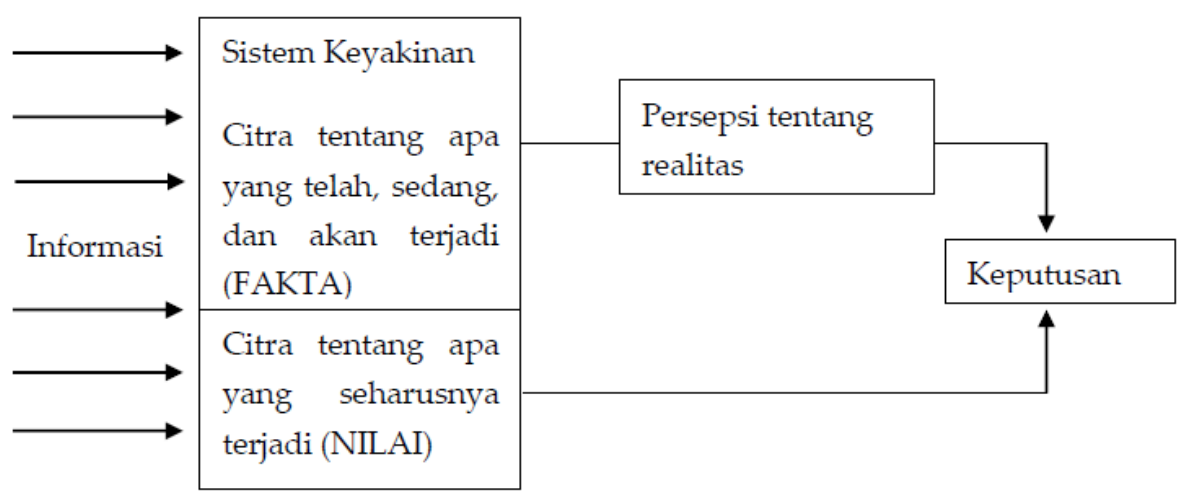

Sumber: Holsti (dalam Russet \& Starr, sebagaimana dikutip oleh Mas'oed, 1991:21). 
Dugaan Suharto terkait keterlibatan Cina dalam peristiwa kudeta 1965 tentunya tidak hanya didasarkan atas adanya fakta historis tentang invasi Cina di masa lalu, tetapi juga diperkuat oleh fakta berupa dinamika politik yang terjadi pada masa akhir pemerintahan Sukarno. Sebagaimana dijelaskan sebelumnya bahwa persaingan sengit terjadi antara militer dan PKI pada masa kepemimpinan Sukarno. Kebijakan Sukarno mengirim Omar Dhani ke Cina dalam rangka mendapatkan bantuan berupa senjatasenjata ringan bagi Angkatan Kelima tidak disetujui oleh militer khususnya Angkatan Darat - pada saat itu karena dinilai melemahkan peranan militer. Peristiwa 1965, oleh karena itu, menimbulkan kesan yang dalam bagi pihak militer, terutama Suharto mengenai keterlibatan Cina dalam peristiwa tersebut. Penilaian akan keterlibatan Cina tidak dapat dilepaskan dari adanya fakta akan adanya upaya PKI untuk membentuk Angkatan Kelima, dengan meminta bantuan terhadap Cina atas persetujuan Sukarno.

Fakta tersebut membuat Suharto menilai bahwa Indonesia seharusnya menghindari interaksi dengan Cina demi kebaikan di masa depan. Ini tampak dari pernyataan Suharto dalam pidato kenegaraan pada 1967, dimana pada saat itu ia mengatakan bahwa: keterlibatan Cina dalam kudeta tahun 1965 dan dukungan terhadap PKI yang terus berlanjut telah mengakibatkan hubungan tidak normal antara dua negara (Suryadinata, 1998:132). Dalam kesempatan lain, pada tahun 1973, Suharto menyampaikan bahwa: Indonesia akan memperbaiki hubungan dengan Cina jika Cina benar-benar bersahabat dan "berhenti" memberikan bantuan serta fasilitas terhadap para mantan pimpinan PKI (Suryadinata, 1998:132). Pernyataan yang disampaikan Suharto diatas merupakan gambaran umum mengenai persepsinya yang menganggap Cina sebagai piha yang berkaitan erat dnegan PKI, dan oleh karenanya menjadi suatu ancaman bagi Indonesia.

Bagi Suharto, interaksi dengan Cina berpotensi membangkitkan kembali PKI yang telah ia bubarkan sejak awal kepemimpinannya, dan menurutnya hal tersebut merupakan ancaman besar bagi Indonesia. Kekhawatiran Suharto akan ancaman PKI tampak dalam beberapa pernyataannya dalam biografinya (Rohman, 2003), seperti: Sekali lagi, setelah sekian banyak kali, saya menyerukan agar kita hati-hati dengan paham-paham yang ekstrim, yang ekstrim kiri dan yang ekstrim kanan... Paham Komunisme bertentangan dengan dasar-dasar Pancasila, harus kita larang penyebarannya dalam masyarakat... Kita menghendaki dan melarang partai komunis di bumi Indonesia, karena PKI telah dua kali 
memberontak dan bertujuan mengubah Pancasila dengan kekerasan. Oleh karena itu, menjalin hubungan dengan Cina, yang saat itu tengah gencar menyebarkan paham Komunisme di bawah pimpinan Mao, merupakan suatu hal yang harus dihindari.

Sistem keyakinan Suharto yang diperkuat oleh penilaiannya tentang "apa yang telah terjadi" dan "apa yang seharusnya terjadi," sebagaimana dijelaskan diatas, selanjutnya membentuk persepsinya tentang Cina. Dengan demikian, jika melihat pada sistem keyakinan Suharto, maka persepsinya yang memandang Cina sebagai ancaman adalah sesuatu hal yang wajar. Persepsi Suharto kemudian mempengaruhi tindakannya untuk memutuskan hubungan diplomatik antara Indonesia dengan Cina pada 1967.

\section{Kesimpulan}

Perubahan rezim kepemimpinan Orde Lama ke Orde Baru turut mempengaruhi kebijakan politik luar negeri Indonesia. Salah satu perubahan kebijakan luar negeri pada awal masa Orde Baru ialah pemutusan diplomatik dengan Cina pada 1967, dimana pada masa pemerintahan sebelumnya Indonesia dan Cina sempat memiliki kedekatan hubungan diplomatik yang ditunjukkan dengan adanya poros Jakarta-Beijing. Berdasarkan pada pendekatan teoritis yang dipakai dalam tulisan ini, pemutusan hubungan diplomatik Indonesia terhadap Cina pada tahun 1967 dipengaruhi oleh persepsi Suharto yang menganggap Cina sebagai ancaman bagi Indonesia dan turut terlibat dalam peristiwa 1965. Persepsi Suharto tersebut dipengaruhi oleh sistem keyakinannya yang dibentuk oleh adat budaya Jawa dan diperkuat oleh penilaiannya mengenai "apa yang telah terjadi", berupa peristiwa 1965 yang sebelumnya sempat diwarnai oleh kebijakan Sukarno berupa pengiriman delegasi ke Cina untuk mendapatkan bantuan persenjataan ringan sebagai upaya memperkuat Angkatan Kelima, dan "apa yang seharusnya terjadi," berupa pandangan Suharto yang mengharuskan Indonesia untuk menghindari interaksi dengan Cina. Dengan demikian, hasil temuan dalam tulisan ini menunjukkan bahwa persepsi seorang pemimpin negara dapat mempengaruhi kebijakan luar negeri negara yang dipimpinnya. 


\section{Daftar Pustaka}

Bunnell, F.P. Guided Democracy Foreign Policy: 1960-1965 President Sukarno Moves from Non-Alignment to Confrontation. Indonesia, 2 (Oct., 1966), pp. 37-76.

Holsti, K.J. (1987) Politik Internasional: Suatu Kerangka Analisis. Bandung: Binacipta.

Jones, W.S. (1992) Logika Hubungan Internasional. Jakarta: Gramedia Pustaka Utama.

Mansbach, R.W. \& Raffety, K.L. (2012) Pengantar Politik Global. Bandung: Nusa Media.

Mas'oed, M. (1991) Studi Hubungan Internasional: Tingkat Analisis dan Teorisasi. Jakarta: LP3ES.

Nabbs-Keller, G. (2011). Growing Convergence, Greater Consequence: The Strategic Implications of Closer Indonesia-China Relations. Security Challenges, 7 (3), Spring, pp. 23-40.

Pareira, Andre H. eds. (1999) Perubahan Global dan Perkembangan Studi Hubungan Internasional. Bandung: Parahyangan Centre For International Studies (PACIS), PT. Citra Aditya Bakti.

Rohman. A. (2013) Memahami Falsafah Hidup Pak Harto: Hakikat Hidup [Online], Tersedia dalam: <http://soeharto.co/mehamai-filsafat-hiduppak-harto> [Diakses 7 November 2015].

Rosyidin, M. (2015) The Power of Ideas: Konstruktivisme dalam Studi Hubungan Internasional. Yogyakarta: Tiara Wacana.

Smith, A.L. (2003) From Latent Threat to Possible Partner: Indonesia's China Debate. Tersedia dalam: $<$ http://apcss.org/Publications/SAS/ChinaDebate/ChinaDebate_SmithIndo .pdf $>$ [Diakses 7 November 2015].

Suryadinata, L. (1998) Politik Luar Negeri Indonesia di Bawah Suharto. Jakarta: LP3ES.

Vatikiotis, M.J. (1993) Indonesian Politics Under Soeharto: The Rise and Fall of the New Order. London: Routledge.

Waltz, K.N. (1979) Theory of International Politics. Massachusetts: Addison Wesley Publishing Company.

Wuryandari, G. eds. (2008) Politik Luar Negeri Indonesia di Tengah Pusaran Politik Domestik. Yogyakarta: Pustaka Pelajar. 